\title{
Multiple Paths to PeACE: PUBlic PARTICIPATION FOR TRANSFORMATIVE AND SUSTAINABLE PEACE PROCESSES
}

\author{
Kristian Herbolzheimer ${ }^{1}$ \\ Director of Philippines and Colombia \\ programmes - Conciliation Resources
}

SUMMARY: Mainstream peacemaking is dominated by the assumption that peace is forged at a negotiating table and that a peace agreement will deliver change for the better. But reality suggests a different picture. With limited ownership and legitimacy most peace agreements collapse, and when they don't their record of implementation remains frustratingly low. This article suggests the need to develop innovative thinking and practice to allow more effective and sustainable peace processes. There is a need for a change of paradigm: to demystify the negotiating table as the core space for deliberation and decision-making and more explicitly acknowledge the importance of parallel or alternative more inclusive spaces and processes of dialogue and agreements on the structural change that will bring transformative peace for society at large. Peace negotiations may be essential for a peace process, but a peace process needs to involve actors and trigger discussions beyond the negotiating table. There are multiple paths to peace, all of them important.

KeYWORDs: public participation, civil society, peace agreements, peace processes.

1. Kristian has been working as a peace analyst and practitioner over the past 15 years, first with the School of Peace of the Autonomous University of Barcelona (20002007) and since 2009 with Conciliation Resources. He represents Conciliation Resources in the International Contact Group on Mindanao that witnesses the peace negotiations and provides assistance to the Government of the Philippines, the Moro Islamic Liberation Front and the Malaysian facilitator. He has also been involved extensively supporting peace initiatives in Colombia and in the Basque Country. 
RESUM: Els processos de pau convencionals se solen regir pels supòsits que la pau s'assoleix en la mesa de negociacions i que un acord de pau farà que les coses canvien a millor. Tanmateix, la realitat és molt diferent. La majoria d'acords fracassen per falta d'assumpció i legitimitat, i quan no és així, el grau d'aplicació és molt baix. L'article planteja la necessitat de desenvolupar pensaments i pràctiques innovadores conduents a processos de pau més transformadors i sostenibles. Cal canviar el model: desmitificar la taula de negociacions com l'àmbit principal en el qual deliberar i prendre decisions, així com reconèixer explícitament la importància d'espais i processos de diàleg $\mathrm{i}$ acords paral·lels o alternatius més inclusius sobre canvis estructurals que permeten d'assolir una pau transformadora a la societat en general. Si bé les negociacions de pau poden resultar importants en els processos de pau, aquests han d'implicar-hi els actors i generar debats més enllà de la mesa de negociacions. Les vies cap a la pau són múltiples, i totes resulten importants.

Paraules Clau: participació ciutadana, societat civil, acords de pau, processos de pau.

RESUMEN: Los procesos de paz convencionales se suelen regir por los supuestos de que la paz se consigue en la mesa de negociaciones y de que un acuerdo de paz hará que las cosas cambien a mejor. Sin embargo, la realidad es muy diferente. La mayoría de acuerdos fracasan por falta de asunción y legitimidad, y cuando no es así, su grado de aplicación es muy bajo. Este artículo plantea la necesidad de desarrollar pensamientos y prácticas innovadoras que conduzcan a procesos de paz más transformadores y sostenibles. Es necesario cambiar el modelo: desmitificar la mesa de negociaciones como el ámbito principal en el que deliberar y tomar decisiones, así como reconocer explícitamente la importancia de espacios y procesos de diálogo y acuerdos paralelos o alternativos más inclusivos sobre cambios estructurales que permitan alcanzar una paz transformadora a la sociedad en general. Si bien las negociaciones de paz pueden resultar importantes en los procesos de paz, estos necesitan implicar a actores y generar debates más allá de la mesa de negociaciones. Las vías hacia la paz son múltiples, y todas ellas resultan importantes. 
$\mathrm{M}$ ainstream peacemaking is dominated by the assumption that peace is forged at a negotiating table and that a peace agreement will deliver change for the better. But reality suggests a different picture. With limited ownership and legitimacy most peace agreements collapse, and when they don't their record of implementation remains frustratingly low. This article suggests the need to develop innovative thinking and practice to allow more effective and sustainable peace processes. There is a need for a change of paradigm: to demystify the negotiating table as the core space for deliberation and decision-making and more explicitly acknowledge the importance of parallel or alternative more inclusive spaces and processes of dialogue and agreements on the structural change that will bring transformative peace for society at large. Peace negotiations may be essential for a peace process, but a peace process needs to involve actors and trigger discussions beyond the negotiating table. There are multiple paths to peace, all of them important.

\section{Peaceful settlement of armed conflict is becoming mainstream policy}

The Global War on Terror that emerged after the September 11 Al Qaeda attacks on New York and Washington has been a failure. Addressing security threats strictly with counter insurgency responses has provenunsuccessful: a survey of 89 case-studies could not find one single example that could be equated to an unambiguous conventional success like that of the Allies in World War II (Jones and Libicki, 2008). It is increasingly clear thateven facing the most heinous atrocities, the need for dialogue persists (Powell, 2014).

Governments like Colombia and Turkey, who had jumped on the waron-terror bandwagon to brand their internal insurgencies as terrorists-without-political-motivation, are now conducting direct peace conversations with armed opposition groups.

Experience has actually proven that peaceful settlement of armed conflicts is more effective than military approaches (Fisas, 2014). As table 1 illustrates, the first years after the end of the Cold War experienced a significant increase in the number of peace agreements paralleled with a decrease in the number of armed conflicts (Harbom et. al., 2006). The Human Security Center (2005) 
suggested these positive trends were due to a better understanding by the international community of the complexity of peace processes, and a better capacity to respond to these challenges.

\begin{tabular}{|l|l|}
\hline Year & Peace agreements \\
\hline 1990 & Colombia (M-19). Lebanon \\
1992 & Moçambique \\
1993 & South Africa \\
1994 & Guatemala \\
1995 & Bosnia, Croatia \\
1996 & Philippines (MNLF) \\
1997 & Tajikistan \\
1998 & Northern Ireland \\
1999 & Timor Leste \\
2000 & Ethiopia-Eritrea. Sierra Leone. Burundi \\
\hline
\end{tabular}

Table 1: Major peace agreements after the Cold War

\section{Peace negotiations are a rough road}

Despite these developments, moving from policy to practice remains challenging. "Peacemaking may have become more difficult as the conflicts are more complex, and may require a highly concerted effort." (Harbom and Wallensteen 2010: 503). The longer a conflict last, the longer it will take to terminate it (Fisas, 2008). Most current armed conflicts fall into the category of protracted armed conflicts (Harbom and Wallensteen, 2007; DeRouen et. al, 2009), which poses specific challenges for peacemaking.

A typical peace process will focus on bringing the armed groups to a negotiating table and forge a peace agreement.This classicalapproach implies several stages:

The first step begins with "talks about talks", that is: people exploring the appetite and eventual conditions for direct talks between warring factions. There is hardly any armed conflict without some effort to promote a peaceful 
settlement. Most often unnoticed, a myriad of local and international initiatives are constantly exploring options to solve or prevent violence through dialogue. A number of factors will influence the decision of state as well as non state armed groups to engage in direct conversations, and it takes many and diverse exploratory actions to eventually bring the enemies face to face.

The second step will normally focus on secret talks. Parties have direct contact with each other (normally through trusted delegates of the respective commanding structures) with the purpose of agreeing on the framework for public talks, such as agenda, venue, facilitation, and external support. Secret talks are very fragile and hardly ever does one single effort produce the needed trust and commitment to move the process to the next step.

When successful, secret talks lead to formal peace negotiations. While these often are announced publicly they will normally be conducted with high levels of confidentiality. Formal talks immediately put parties to the talks under hard pressure from all sectors from society: from those endorsing a peaceful settlement as well as those opposed to compromise.

Peace negotiations often collapse (Walter, 2010). In some cases this leads to resumption of violence; on other occasions the consequence is a state of 'no war and no peace'where fighting may continue but at a very low intensity, or rebels may give up their struggle by violent means (Fortna, 2005; Kreutz, 2010).

It is therefore not surprising that negotiations that deliver a peace agreement are often considered to have achieved their ultimate goal. A peace agreement is indeed often associated with the end of the armed conflict, and expectations for early peace dividends are high.

But experience proves that implementation of a peace agreement can be even more challenging than the negotiations themselves (Stedman, 2002). Recent empirical data suggest that peace agreements are never fully implemented. ${ }^{2}$ Table 2 illustrates developments after the signing of some of the most significant peace agreements.

2. See Peace Accord Matrix: https://peaceaccords.nd.edu/matrix/topic/, accessed 21 November 2014. 


\begin{tabular}{|c|c|c|}
\hline Year & Agreement & Developments \\
\hline 1994 & Guatemala & $\begin{array}{l}\text { The Constitutional reforms agreed at the negotiating table where } \\
\text { not endorsed by the people in a plebiscite. } \\
\text { The implementation of the peace agreement is still subject of } \\
\text { negotiations. }\end{array}$ \\
\hline 1998 & Northern Ireland & $\begin{array}{l}\text { Communities remain largely segregated and intra-party trust is } \\
\text { low. }\end{array}$ \\
\hline 2005 & $\begin{array}{l}\text { Liberia } \\
\text { Sudan }\end{array}$ & Positive developments but major development related challenges. \\
\hline 2005 & Colombia (AUC) & War relapsed shortly after the South voted for independence. \\
\hline 2006 & Nepal & $\begin{array}{l}\text { Huge numbers of former combatants have continued their crimi- } \\
\text { nal activity. }\end{array}$ \\
\hline & & $\begin{array}{l}\text { Ten years after the peace agreement the parties are yet to agree on } \\
\text { a new Constitution. }\end{array}$ \\
\hline
\end{tabular}

Table 2: Post-agreement developments

In other words: most efforts to promote peace negotiations fail; most peace negotiations don't achieve a peace agreement; peace agreements don't always hold; and on the rare occasions parties stick to their commitment, the results never meet people's expectations for change.

This daunting diagnosis points to a very limited efficiency in mainstream peacemaking. While the what is clear -the goal of settling political confrontation through dialogue- the how remains an open question (Arnault, 2006).

There is a need to improve the quality of peace processes, in terms of their capacity to bring about transformative and lasting change for the benefit of the whole of society.

\section{Mainstream peace negotiations suffer a democratic deficit}

One of the core difficulties in improving the quality of a peace process are the conceptual confusions around how a peace process works and the unmet expectations of what a peace process can deliver. 
Peace negotiations are almost by definition profoundly antidemocratic. They are elitist in that a small number of people take decision that affect the whole of the population. They are male dominated and thereby imposing a specific gender perspective. By being necessarily confidential they unavoidably lack transparency. They indirectly reward violence, as essentially those who take up arms become a seat at the table, marginalizing the nonviolent movements for change. And they promote impunity as most conflict-related human rights violations are not addressed.

This democratic deficit of many peace negotiations limits their capacity to produce transformative and lasting change for the better.

Peace processes can therefore be classified according to their degree of inclusion:

\begin{tabular}{|l|l|l|l|l|}
\hline Elitist & Consultative & Representative & Gradual & Unilateral \\
\hline Philippines (NDF) & $\begin{array}{l}\text { Philippines } \\
\text { (MNLF; MILF) }\end{array}$ & Southafrica & Colombia (current) & Colombia \\
Israel-Palestine & Colombia & N. Ireland & Nicaragua & (M-19) \\
Indonesia (Aceh) & $(1999-2002)$ & Nepal & (East Coast) & $\begin{array}{l}\text { México } \\
\text { (Chiapas) }\end{array}$ \\
Angola & Guatemala & Burundi & $\begin{array}{l}\text { Philippines } \\
\text { (RPMM) }\end{array}$ & $\begin{array}{l}\text { Basque Coun- } \\
\text { try }\end{array}$ \\
Sudan & Nagaland & Somalia (Puntland) & & \\
Colombia (AUC) & (India) & & & \\
Western Sahara & & & &
\end{tabular}

Table 3: Models of peace processes

Developments over the past years suggest an increasing consensus on the need for more inclusive, gender-balanced, and accountable processes.

While the relevance of public participation has long been an intuitive assumption (Lederach, 1998; Barnes, 2002), it was not until recently that research could provide clear evidence of the increase of sustainability of inclusive peace processes (Nilsson, 2012). As so often, practice has preceded policy and theory and a number of cases from around the world today inform the growing body of knowledge on inclusive peace processes (González et. al., 2009; Paffenholz, 2014). 
In parallel the past decade or so has witnessed a significant push for women's participation in peace negotiations. UN Security Council Resolution 1325 of 2001 (and the subsequent resolutions 1820, 1888, 1889, 1960) have had a major impact in unveiling the gender-blind approach in peace negotiations and suggesting ways to remedy this situation. While response to this challenge has been slow (Bell and Rourke, 2007), recent developments in the Philippines (OPAPP, 2014) and in Colombia ${ }^{3}$ suggest that the message is getting through.

Finally, thanks to the perseverance of human rights advocates peace agreements can no longer turn a blind eye on atrocities committed during the armed confrontation. The UN system, for instance, cannot endorse any peace agreement that provides blanket amnesty for human rights violations. For some years human rights and peace have been portrayed as mutually incompatible concepts. But another positive development is the growing consensus that there cannot be just and lasting peace without human rights, while peace is essential to prevent further human rights violations (Parlevliet, 2009).

The developments in these three fields (inclusion, gender-sensitivity, human rights) are a welcome development in the quest for more transformative and sustainable peace processes. Nevertheless these developments still tend to focus on the negotiating table as the centerpiece of a peace process. Most advocacy for civil society participation and, more specifically women's participation, is indeed focused on getting slots at the negotiating table or, as a second best alternative, to influence the agenda of the negotiations to ensure it covers aspects that the warring parties may not necessarily consider. This approach inadvertedly nurtures the asymmetry between the relevance given to peace negotiations and the need for additional, parallel, sometimes even alternative paths to peace.

\section{Peace negotiators innovate for more inclusive processes}

The paradox is that peace negotiators and peace mediators themselves seem to be increasingly aware of their own limitations. Especially in

3. See http://www.elespectador.com/noticias/paz/se-instala-subcomision-de-genero-losdialogos-de-paz-articulo-515215, accessed 21 November 2014. 
countries with protracted armed conflict, where peace negotiations have failed time and again, parties to the negotiations are aware of the need to increase the legitimacy of peace negotiations through more inclusive processes.

An early case were the last attempt of negotiations between the Basque armed group ETA and the Spanish Government in 2004. The parties had agreed to establish two parallel tables: one for the two armed actors to settle the violence and its "consequences" (victims, prisoners, etc); and another one where all political parties together with trade unions, business associations and other actors from civil society would discuss the substantive agenda of the peace process (Fisas, 2007). None of these tables were ever convened as the process failed in its early stages. But this notion of inclusivity has remained in peace advocacy circles and the Lokarri peace movement has recently been nurturing a civil society dialogue even in the absence of formal talks (Ríos, 2014).

Another recent example is the peace negotiations on Mindanao. The Government of the Philippines signed a Final Peace Agreement with the Moro National Liberation Front (MNLF) back in 1996. Almost two decades after both parties are still discussing the implementation of that agreement. Learning the lessons from that process, the Government and another armed group -the Moro Islamic Liberation Front (MILF) - have agreed on the conditions for a more solid process, which can be summarized with: a) continuous consultations with all sectors of society before and after the signing of a peace agreement; $b$ ) a regional constitution to be drafted in a participatory process, enacted by Congress, and ratified in a plebiscite by the people in the conflict-affected areas; $c$ ) and a sophistic agreement implementation infrastructure with hybrid bodies composed of national and international, social and institutional, and partisan and independent delegates. A Third Party Monitoring Team has the mandate to oversee and assess parties' performance in agreement implementation and eventually ratify the successful completion.

A third interesting development is the proliferation of National Dialogues to promote broad and inclusive discussions for structural transformation (Ramsbotam and Wennman, 2014; Siebert, 2012). As table 4 
shows, these processes can either take place before or after peace negotiations; or they can replace traditional negotiations altogether. They can include a small number of people or they can be extremely broad.

\begin{tabular}{|l|l|}
\hline Case & Notes \\
\hline Philippines & $\begin{array}{l}\text { A national consultation that led to the framework of Six Paths to } \\
\text { Peace. }\end{array}$ \\
Ayanmar & $\begin{array}{l}\text { A formal process for drafting the new Constitution. } \\
\text { A formal process in the absence of peace negotiations. } \\
\text { Bemen }\end{array}$ \\
Basque Country & $\begin{array}{l}\text { An informal dialogue led by civil society organizations in the ab- } \\
\text { sence of peace negotiations. }\end{array}$ \\
\hline
\end{tabular}

Table 4: Modalities of National Dialogue

Maybe the most significant development along these lines are the peace negotiations between the Government of Colombia and the Armed Revolutionary Forces of Colombia (FARC). Before beginning their fourth attempt of formal talks, both parties carefully analyzed the lessons from previous negotiations, both Colombian and international. As a result of this analysis the Framework Agreement that the parties jointly announced in September 2012 provides a major conceptual innovation in that it differentiates between the peace negotiations -in Cuba, between Government and FARC only, with a limited agenda- "to put an end to the armed conflict", and a broader process for building peacethat will take place in Colombia, after the signing of a peace agreement, "with the participation of all citizens". ${ }^{4}$

The table below illustrates the development in the thinking of both parties from their previous attempt of peace negotiations.

4. See Acuerdo General para la Terminación del Conflicto: https://www.mesadeconversaciones.com.co/sites/default/files/AcuerdoGeneralTerminacionConflicto.pdf, accessed 21 November 2014. 


\begin{tabular}{|c|c|c|}
\hline & Caguán process (1999 - 2002) & Havana process (20I2 - ?) \\
\hline Goal & $\begin{array}{l}\text { To agree on structural change of the } \\
\text { country. }\end{array}$ & To put an end to the armed conflict. \\
\hline Assumptions & $\begin{array}{l}\text { Negotiations will lead to an agree- } \\
\text { ment that will address all root causes } \\
\text { of the conflict. }\end{array}$ & $\begin{array}{l}\text { Negotiations will stop the war and } \\
\text { enable a new phase which will allow } \\
\text { for inclusive, transparent, delibera- } \\
\text { tion and decision-making on the root } \\
\text { causes of the conflict and additional } \\
\text { challenges that have developed over } \\
\text { the past years. }\end{array}$ \\
\hline Agenda & Broad (100 points) & Narrow (5 points) \\
\hline Actors & $\begin{array}{l}\text { Government and FARC saw them- } \\
\text { selves as the true representatives of } \\
\text { society. }\end{array}$ & $\begin{array}{l}\text { Government and FARC understand the } \\
\text { need for public participation and dem- } \\
\text { ocratic decision-making. }\end{array}$ \\
\hline $\begin{array}{l}\text { Public partici- } \\
\text { pation }\end{array}$ & $\begin{array}{l}\text { Symbolic. Parties organized public } \\
\text { hearings but people's inputs were } \\
\text { never seriously analyzed and consid- } \\
\text { ered. }\end{array}$ & $\begin{array}{l}\text { Fundamental. Multiple formats of } \\
\text { direct and indirect participation. All } \\
\text { contributions are systematized and } \\
\text { analyzed by the parties and supporting } \\
\text { organizations (National University, } \\
\text { UN). }\end{array}$ \\
\hline $\begin{array}{l}\text { Time-frame } \\
\text { and frequency }\end{array}$ & $\begin{array}{l}\text { Open-ended (years), with on-off } \\
\text { talks. }\end{array}$ & $\begin{array}{l}\text { Narrow (urgency to complete the nego- } \\
\text { tiations), with } 10 \text { day long sessions in- } \\
\text { terrupted by one week of consultations. }\end{array}$ \\
\hline Developments & $\begin{array}{l}\text { Parties got stuck with procedural } \\
\text { issues and never began discussing the } \\
\text { substance of the agenda. }\end{array}$ & $\begin{array}{l}\text { Parties reach agreements on: } \\
\text { - Land and rural development (2013). } \\
\text { - Political participation (2014). } \\
\text { - Illegal drugs (2014). } \\
\text { Remaining agenda items: } \\
\text { - Victims. } \\
\text { - Disarmament. }\end{array}$ \\
\hline
\end{tabular}

Table 5: Differences in the design of the two latest peace negotiations with FARC

\section{There is a need to balance the asymmetry between peace approaches}

The quest for increasing legitimacy is essentially an effort to balance top-down elite negotiations and bottom-up claims for participation. Both approaches are necessary and mutually dependent.

In order to clarify the peace architecture it isimportant to differentiate between peace negotiations and the broader peace process. These two con- 
cepts are often used interchangeably, which leads to significant confusion. It is important to be aware and to highlight that peace negotiations are (most often) a fundamental component of a peace process; but a peace process is much broader than peace negotiations.

When identifying an overall framework that can encompass these two perspectives it might be helpful to identify the core questions that underlie any peace process: What is the peace process trying to address? Who will decide on the necessary change? How will deliberation and decision-making take place? And When will change happen? In other words, the four driving factors of a peace process can be described as the agenda, the actors, the processes and the time-frame.

Current advocacy for participatory processes is essentially table-centric in that it suggests that for a peace process to be more inclusive there is a need to add more items to the negotiating agenda, and more actors to the negotiating table. The assumption nurturing this advocacy is that the negotiating table is the core place where decisions are taken.

A radically different approach would instead suggest balancing the power asymmetry between the negotiating table and other deliberation and decision-making processes. Assuming the inherent democratic deficit of a negotiating table, efforts for a more legitimate peace could pay more attention to identifying and exploring the multiple paths to peace that are necessary for a process to be truly inclusive and, thereby, transformative and sustainable.

The exercise of demistifying the negotiating table as the core pillar of a peace process opens up a universe of options for more issues to be discussed, more actors to be involved, more processes to be initiated, and more time for transformations to take place.

\section{Multiple paths to peace: a new metaphor}

Metaphors are powerful tools: they help capture complexity and shape people's worldview. As knowledge develops metaphors also need to adjust.

The predominant metaphor that frames current thinking around the role of different actors in a peace process is the concept of "multi-track diplomacy". 
According to the us Institute of Peace glossary track one refers to formal negotiations; track two are "unofficial dialogue and problem-solving activities aimed at building relationships and encouraging new thinking that can inform the official process"; and track three entails "people-to-people diplomacy undertaken by individuals and private groups to encourage interaction and understanding between hostile communities and involving awareness raising and empowerment within these communities". Some authors have suggested a number of additional tracks. ${ }^{6}$

The track metaphor has been very important in acknowledging the presence of peace efforts beyond the peace negotiations. But the metaphor also has three less constructive implications given its hierarchical, linear and static connotations.

The numbering of tracks indeed suggests a hierarchy, where peace negotiations take the preeminent role, which all other tracks feed in to. Shortcomes in agreement implementation instead alert that peace agreements are not self-implementing, no matter how well crafted. The Guatemala peace accord (1994) is a very comprehensive and ambitious agreement in terms of structural change. But its implementation failed due to lack of buy-in from the political opposition and the population in general. Parallel processes for discussing structural change are at least as important as the formal peace talks. In some cases like the Southern Caucasus, the Basque Country or Kashmir, the absence of formal talks leaves no other option for peace to progress than through parallel informal paths.

Further, the track metaphor reminds of railway tracks, which are rigid and offer limited flexibility to adjust to the changing circumstances along a peace process.

Finally, peace processes (and any social process for that matter) are never linear and causal in their development, but rather complex and chaotic. Lederach suggests replacing the track metaphor with the idea of platforms which "have a continuous generative capacity that is responsive to longer-term rela-

5. http://glossary.usip.org/resource/tracks-diplomacy, accessed 26 July 2014.

6. Notably the Institue for Multitrack Diplomacy: http://www.imtd.org, accessed 26 July 2014. 
tional patterns and is adaptive to changing environments" $(2005 ; 182) . \mathrm{He}$ highlights the importance of paying attention not only to the visible conflict symptoms but also to the nature of social and human change.

There is therefore a need for a metaphor that is flexible and inclusive enough to properly acknowledge and value all peace actors and processes, and the importance of building trust and relations between people who have experienced conflict in very different ways.

In this article we are suggesting the metaphor of multiple paths to peace as a framework that can encompass all the peace efforts that, together, compose a peace process.

The 'paths' metaphor offers a more horizontal and flexible framework, where no path has necessarily preeminence over the other.Paths can be wide and narrow, dry or dirty; they can run parallel, they may cross or they at times overlap. More importantly, they are shaped by people walking them, and their shape adjusts to the changing landscape.

The concept of "paths to peace" was developed in the Philippines in 1993 (Coronel, 2002). In close collaboration with civil society organizations the Government organized consultations throughout the country to ask the people about the causes and the responses to armed conflict.The resulting recommendations were integrated to produce what many consider to be the classic framework guiding Philippine peacemaking: the Six Paths to Peace. Peace negotiations are one of the paths. But there are five more that run parallel (and sometimes independently):the pursuit of social, economic, and political reforms aimed at addressing the root causes of conflict; consensus building and empowerment for peace through continuous consultation at the national and local levels; implementing measures for reconciliation and reintegration of former combatants, and rehabilitation of those affected by the conflict; conflict management and protection of civilians; and finally the commitment to nurture and enhance a positive climate for peace.

The same way the Philippines conceptualized their own Six Paths to Peace, any peace process in the world can identify and name their own paths to peace. 
Inspired by the Philippine case, the Women Peace and Security Collective in Colombia has developed a manifesto, an Ethical Pact for Peace that salutes the formal peace talks but suggests 15 additional paths the country needs to walk in order to achieve just and lasting peace. ${ }^{7}$

\section{Implications for practice}

While there is no formula as to the right number and name of paths to peace, the table below illustrates some paths that are probably relevant for most contexts:

\begin{tabular}{|l|l|}
\hline Path & The formal path, which often is wrongly labeled as peace process. \\
\hline Negotiations & $\begin{array}{l}\text { The discussions and decisions taken at the executive, legislative and judiciary } \\
\text { level. }\end{array}$ \\
\hline Social & The initiatives taken by civil society, academic institutions, etc. \\
\hline Local & Cross-sectoral dialogue among all stakeholders in the conflict-affected regions. \\
\hline Sectoral & $\begin{array}{l}\text { Intra-sectoral dialogue in social movements, trade unions, business sector, faith } \\
\text { communities, security sector, etc. }\end{array}$ \\
\hline Principled & $\begin{array}{l}\text { Cross-cutting principles that are fundamental to inform the change that needs to } \\
\text { happen, like human rights and women's empowerment. }\end{array}$ \\
\hline Cultural & $\begin{array}{l}\text { Most cultures of the world have deep rooted conceptions and worldviews that } \\
\text { praise violence and nurture prejudice. }\end{array}$ \\
\hline Personal & $\begin{array}{l}\text { Change in society is only possible if people are willing to commit for a common } \\
\text { good at a personal level. For some people this is a spiritual journey. The person- } \\
\text { al path also includes the need for dealing with the past. }\end{array}$ \\
\hline
\end{tabular}

Table 6: Common paths to peace

The multiple paths to peace can be conducive to formal negotiations; they may be needed for agreement implementation; or they can be developed in the absence of formal negotiations.

The metaphor of paths to peace also suggests the absence of any centralized design of a peace process. Beyond the formal peace negotiations, other paths are initiated autonomously by citizens and institutions, sometimes in a coordinated manner, most often spontaneously.

7. See: http://pactoetico.org/, accessed 6 November 2014. 
The multiple paths metaphor is essentially a framework that allows all actors in a peace process to identify their niche of action, as well as the interdependence with the other paths.

Bringing back the four core variables of a peace process mentioned earlier, the multiple paths to peace allow to re-assess the actors, the agenda, the processes and the time-frame for a peace process.

If multiple paths to peace are given their due acknowledgement the emphasis in promoting public participation and influencing the peace agenda does not necessarily fall on the formal peace negotiations any more. The very contrary might be the case: that peace talks between State and insurgency should have a narrow political agenda focused on terminating the armed confrontation, and thereby enabling a more democratic and thereby legitimate, transformative and sustainable peace processes to take over. In other words, limit the expectations to what the peace agreement should deliver and instead focus much more attention and efforts in developing more participatory processes of deliberation and decision-making.

At the same time, this framework makes it easier to identify the peace dividends that may be achieved at different moments in time. In order to prevent public frustration and further unrest, it is important to identify clearly what the short, mid, and long term deliverables of a peace process; and to identify the people, organizations and institutions responsible for those deliverables.

If the peace process goes well, the most significant short term deliverable is the termination of the war. This is a huge achievement in itself, especially in contexts of high intensity confrontation or where armed conflict has been going on for many years. Legislative change and other reform will probably take a few years to develop. And the structural as well as the personal change may take decades (Herbolzheimer, 2009).

A peace agreement should deliver the silencing of the guns, what Galtung (1969) described as negative peace. The positive peace -the structural change that addresses the root causes of armed conflict- will need to be addressed by society at large, and will take longer. 


\section{References}

Arnault, J. (2006): Good Agreement? Bad Agreement? An Implementation Perspective, Centre of International Studies, Princeton University, Princeton, $<$ http://id. cdint. org/content/documents/Good_Agreement_Bad_Agreement.pdf $>$.

Barnes, C. (2002): Owning the Process: Public Participation in Peacemaking, Accord, 13, Conciliation Resources.

Bell, C. \& C. O'Rourke (2007): «The People's Peace? Peace Agreements, Civil Society, and Participatory Democracy», International Political Science Review, 28(3), 293-324.

Coronel Ferrer, M. (2002): Philippines National Unification Commission: National consultations and the 'Six Paths to Peace', Accord, 13, Conciliation Resources.

DeRouen, K.; J. Lea \& P. Wallensteen (2009): «The Duration of Civil War Peace Agreements», Conflict Management and Peace Science, 26(4), 367-387.

Fisas, V. (2006-2014): Anuario de procesos de paz, Escola de Cultura de Pau, Icaria, Barcelona.

Fortna, V. (2005): Where Have All the Victories Gone? War Outcomes in Historical Perspective. Paper presented at the annual meeting of the International Studies Association, Honolulu 1-5 March.

Galtung, J. (1969): «Violence, Peace, and Peace Research». Journal of peace research, 6(3), 167-191.

González Posso, C.; K. Herbolzheimer \& T. Montaña Mestizo (Eds.) (2010): La vía ciudadana para construir la paz, Indepaz, Bogotá.

Harbom, L. \& P. Wallensteen (2007): «Armed Conflict 1989-2006». Journal of Peace Research, 44 (5): 621-632.

- (2010) «Armed Conflicts 1946-2009». Journal of Peace Research, 47 (4): 501-509.

Herbolzheimer, K. (2009): «Challenging Political Violence», Journal of Aggression, Conflict and Peace Research, 1(3), 37-47.

Human Security Centre (2005): Human Security Report 2005: War and Peace in the 21st Century, Oxford University Press, Oxford.

Jones, S. G. \& M. C. Libicki (2008): How Terrorist Groups End: Lessons For Countering Al Qa'ida, Rand Corporation.

Kreutz, J. (2010): How And When Armed Conflicts End: Introducing The UCDP Conflict Termination Dataset. Journal of Peace Research 47 (2): 243-250. 
Lederach, J. P. (2005): The Moral Imagination: The Art and Soul of Building Peace. Oxford University Press, Oxford.

- (1998): Construyendo la paz. Reconciliación sostenible en sociedades divididas, Gernika Gogoratuz, Bakeaaz.

Körppen, D.; N. Ropers \& H. J. Giessmann (Eds.) (2011): The Non-Linearity of Peace Processes: Theory and Practice of Systemic Conflict Transformation, Budrich, Berlin.

Nilsson, D. (2012): «Anchoring the Peace: Civil Society Actors in Peace Accords and Durable Peace». International Interactions, 38(2), 243-266.

Opapp (2014): «The Women at the Peace Table», Kababaihan-kapayapaan magazine. Office of the Presidential Adviser on the Peace Process.

Parks, T. \& W. Cole (2010): «Political Settlements. Implications for International Development Policy and Practice». Occasional Paper nr. 2. The Asia Foundation.

Parlevliet, M. (2009): Rethinking Conflict Transformation from a Human Rights Perspective, Berghof Handbook for Conflict Transformation, Berlin.

Paffenholz, T. (2014): «Civil Society and Peace Negotiations: Beyond the Inclusion-Exclusion Dichotomy». Negotiation Journal, 30(1), 69-91.

Powell, J. (2014): Talking to Terrorists: How to End Armed Conflicts. Bodley Head Adults, London.

Ramsbotam A. \& A. Wennman (2014): Legitimacy and Peace Processes: from Coercion to Consent, Accord, 25, Conciliation Resources.

RIos, P. (2014): Basque Country: experiences of the Social Forum to invigorate peace, Accord, 13, Conciliation Resources.

Siebert, H. (2012): «National Peace and Dialogue Structures-Strengthening the Immune. System from Within instead of Prescribing Antibiotics». Berghof Handbook Dialogue Series, (10).

Stedman, S. J.; D. S. Rothchild \& E. M. Cousens (Eds.) (2002): Ending Civil Wars: The Implementation of Peace Agreements, Lynne Rienner Publishers, Boulder.

Walter, B. (2010): Conflict Relapse and the Sustainability of Post-conflict Peace, World Development Report 2011. Background paper. 